\title{
Alstonia scholaris in the ethnomedicinal and religious tradition of Coastal Karnataka, India
}

\author{
M. JAYAKARA BHANDARY" \\ Department of Botany, Dr. P. Dayananda Pai-P. Sathish Pai Government First Grade College. Carstreet Rd., Mangalore-575001, Dakshina Kannada, \\ India. Tel.: +91 824249 4109, `email: mbjaikar@gmail.com, jayakara.bhandary@ka.gov.in
}

Manuscript received: 13 February 2020. Revision accepted: 22 March 2020.

\begin{abstract}
MJ Bhandary. 2020. Alstonia scholaris in the ethnomedicinal and religious tradition of Coastal Karnataka, India. Biodiversitas 21: 1569-1577. The tribal and non-tribal indigenous communities of coastal districts of Karnataka use Alstonia scholaris (L.) R. Br. for the treatment of various ailments such as fever, asthma, leucorrhea, eczema, indigestion and also to heal spider bites. An annual health-related ritual of mass drinking of a bitter juice or decoction of the stem bark of this tree on the new moon (amavasya) day of 'aati' month of the traditional 'tulu' calendar coinciding with the rainy monsoon season is popularly followed in the study area, especially by the rural families. The underlying belief is that this drink keeps away all ailments and ensures wellbeing. The recorded ethnomedicinal uses and the traditional practice of mass drinking of the bitter juice appear to be scientifically meaningful when interpreted on the background of the ayurvedic uses and the wide range of curative properties ascribed to this plant, many of which have been confirmed by reported pharmaco-chemical studies. Studies have also indicated that the toxicity of the bark extract was minimum during monsoon season and the concentration of active principle was maximum in the bark juice collected on the particular new moon day. This further justifies the timing of the described annual medicine drinking event. In addition, some Tulu language-speaking indigenous communities consider this tree as the reincarnation of a mythological demon called Bali and worship its branch during the festival days of Deepavali, in honor of him. Thus, A. scholaris emerges as a plant of great ethnobotanical significance in the study area.
\end{abstract}

Keywords: Alstonia scholaris, Coastal Karnataka, ethnomedicinal tradition, ethnoreligious plant, tree worship, herbal medicine

\section{INTRODUCTION}

Knowledge of indigenous cultures about medicinal uses of local plants is an important input for understanding traditional utilization of biological resources, for promoting community healthcare practices and also for developing modern plant-based drugs. According to an estimate of the World Health Organisation (WHO), about $80 \%$ of the populations in the developing countries rely on traditional medicine for their primary health care needs (Smith-Hall 2012). The available estimates of species of plants used as medicines in the traditional treatment practices of indigenous cultures living around the world are highly variable and range from 20,000 (Vedprakash 1998) to 52,885 (Schippmann et al. 2002). The tribal and indigenous communities of India were found to be using more than 10,000 species of wild plants for various purposes which include about 8,000 species for medicinal uses (Pushpangadan and George 2010). Indigenous culture's knowledge of healing plants is a complex system of practice. It ranges from using them as direct cures in the treatment of health problems to plant-centered beliefs and mystical rituals aimed at preventing illnesses or promoting and ensuring wellbeing. In addition to helping the modern world to understand the traditional people's world view of nature and its components, study of such practices also act as direct and indirect or symbolic indications of curative properties of plants.
India has been proved to be a very rich repository of traditional information on direct uses of and ritualistic practices related to plants, owing to its rich cultural and floristic diversity. The direct ethnomedicinal uses of plants have received considerable scientific attention as multitude of ethnobotanical reports are available from this nation (Binu et al. 1992; Lalramanghinglova and Jha 1999; Pullaiah et al. 2017). Ethnomedicinal practices specific to certain geographical areas, tribal groups and disease categories of Karnataka, a southern state of India, has also been documented (Bhandary and Chandrashekar 2001, 2003, 2009; Bhandary et al. 1995, 1996; Harsha et al. 2003, 2006; Rajkumar and Shivanna 2010). However, plantcentered beliefs and rituals have not been properly documented and analyzed.

Plants play an important role in religious and social ceremonies of indigenous and rural communities all over the world (Manilal 1989), and tree worship is a common practice in various religions of the world, including India (Choudhary 2012). Such practices are based on religious beliefs and world-view of the communities and are responsible for ascribing a sacred status to some plants which also contribute to their conservation.

Alstonia scholaris (L.) R. Br., (Apocynaceae) is a medicinally well known tropical tree native to Indian subcontinent, Australasia and Malay Peninsula. Its medicinal uses are well documented in classical traditional medicinal systems including Ayurveda, and ethnomedicinal systems of different regions of the world (Jain 1991, 
Warrier et al. 1994, Kher 2007, Pratyush et al. 2011, Khyadea et al. 2014,). In this paper, information pertaining to the direct ethnomedicinal uses and a health-related ritual involving Alstonia scholaris in the coastal Karnataka region of India is provided. The possible scientific basis of the recorded practices is discussed based on available pharmacological and phytochemical data pertaining to this plant. In addition, a religious practice of worshipping this tree by some traditional communities of the study area is also described along with the underlying religious belief.

\section{MATERIALS AND METHODS}

\section{Study area}

Dakshina Kannada and Udupi are the two coastal districts of Karnataka State, India, which together constitute an area of $8441 \mathrm{~km}^{2}$. They are located between $12^{0} 29^{\prime} 36^{\prime \prime}$ ' and $13^{\circ} 49^{\prime} 22^{\prime \prime}$ 'N latitudes, and 74037'24' and $75^{\circ} 41^{\prime} 00^{\prime}$ 'E longitudes (Figure 1). The $136 \mathrm{~km}$ long stretch of coastline facing the Arabian Sea forms the western edge of these districts while the towering heights of unbroken stretch of the Western Ghats mark the eastern boundary.

Historically, these two districts, together with the northern part of the adjoining Kasaragod district of Kerala state, constitute the historical 'Tulunadu' (land of Tulu), called so because of the dominance of 'tulu' language speaking people in this area. These districts are the home for several tribal and other indigenous communities such as the Billavas, Bunts, Idigas, Mogaveers, Gowdas, Koragas, Malekudiyas, Kunabis, Maratis and others who have maintained a close association with the components of nature in their surroundings.

The total population of these two districts is $32,67,010$ (Census of India 2011). The area is still predominantly rural and agrarian with about $80 \%$ of the workforce employed in agriculture and allied activities including growing cash crops of coconut, areca nut, and other horticultural products. More than $70 \%$ of cropland is under cereals with rice as the principal crop. Fishing is the other major source of livelihood with about $1,00,000$ people directly engaged in fishing. This region receives heavy rainfall, in the range of 2,500-3,000 $\mathrm{mm}$ and it harbors different types of vegetation such as littoral, scrubs, moist deciduous and typical evergreen. The littoral and the scrub forests are found along the coastal belt, the moist deciduous forests mainly in the inland plateaus extending to the foot of the ghats and the evergreen forests localized only in the ghats. The floristic diversity of this region has been sufficiently studied and documented (Gamble 1967; Saldanha 1984; Bhat 2003).

\section{Methodology}

Information regarding the ethnomedicinal uses and rituals pertaining to $A$. scholaris was gathered from the traditional herbal healers and knowledgeable elders belonging to the different indigenous communities, including two of the tribes namely the Koraga and the Malekudiya, residing in the study area. The study was conducted from August 2014 to December 2015 and it was actually an extended part of a comprehensive ethnobotanical documentation project started in the study area by this author in 1995 which has resulted in many publications (Bhandary and Chandrashekar 2001, 2003, 2009; Bhandary et al 1995, 1996). Data collection was made through prior-informed interviews and discussions. Ex-situ interviews with selected informants using fresh plant material and color photographs of Alstonia scholaris as reference tools were mainly used for data recording (Thomas 2007; Medeiros et al. 2014).
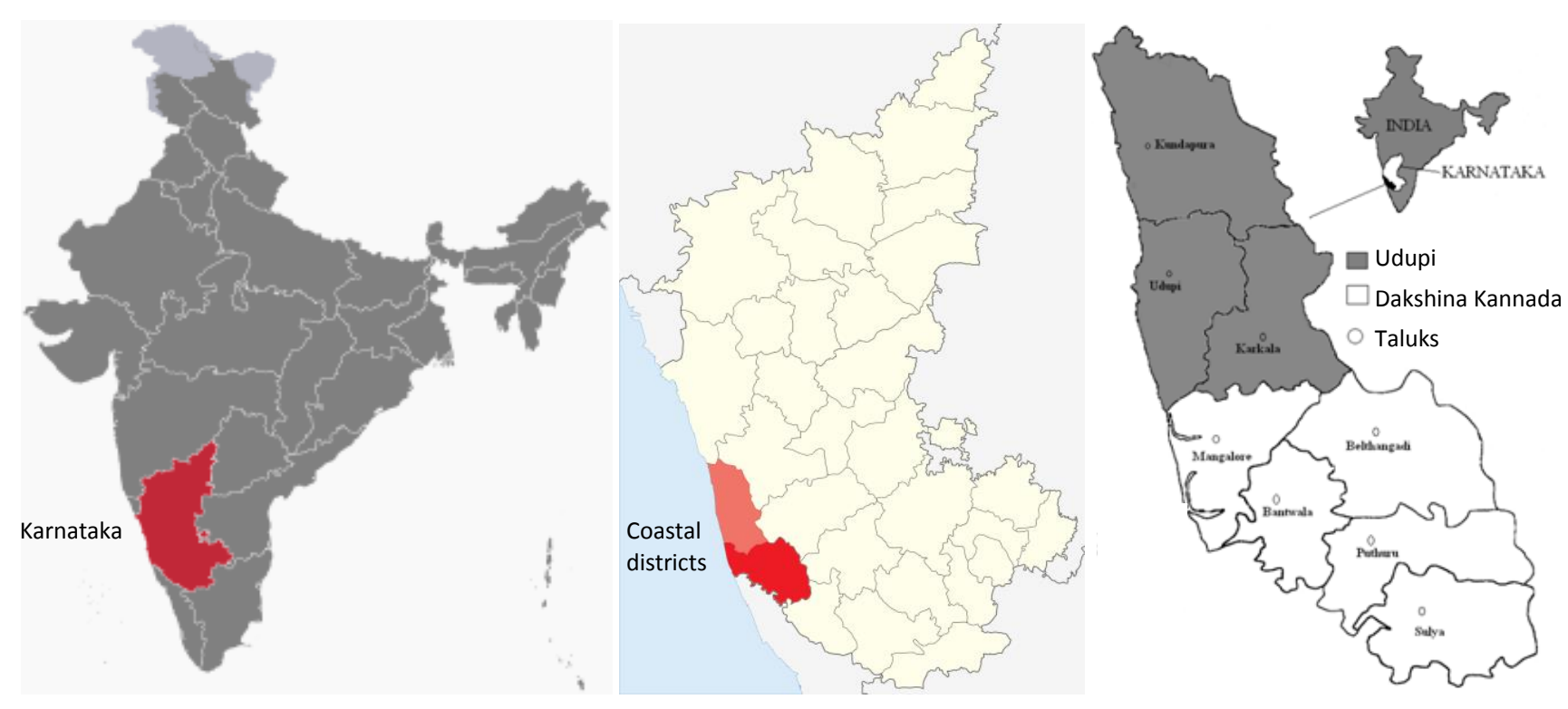

Figure 1. Map of coastal districts of Karnataka State, India 


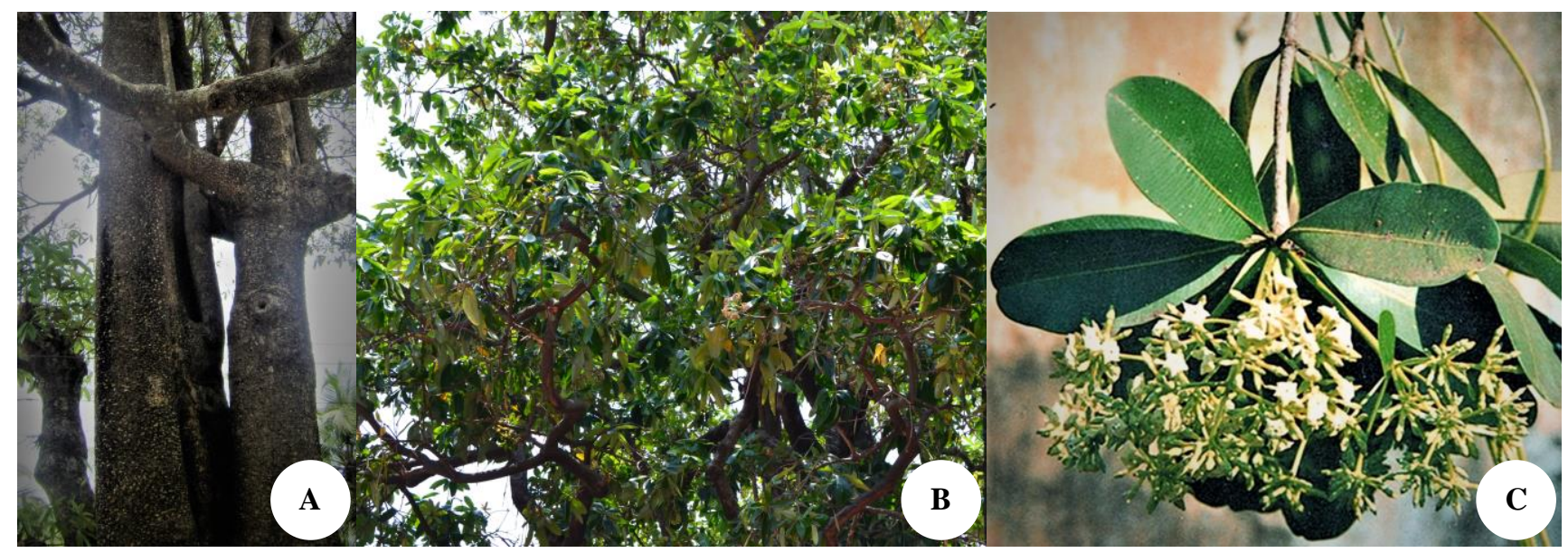

Figure 2. Alstonia scholaris: A. View of trunk portion, B. Canopy view, C. Flowering twig

A total of 13 knowledgeable people were consulted as information sources and the total number of interview sessions conducted was 18 , as five of the informants were interviewed twice during the study period. The author also had the additional advantage and experience of personally participating in the described medical ritual and tree worship ceremonies, as he himself belongs to one of the local traditional communities called the 'Bunts' belonging to the study area. Therefore, the description of the tree worship tradition is mainly based on the personal experience and observation of the author himself which is supported by information gathered by elders of the family regarding the religious background.

\section{Botanical description of Alstonia scholaris}

Alstonia scholaris (L.) R. Br., belonging to the family Apocynaceae, is a large evergreen tree growing commonly in the forests and waysides of the study area. Its a glabrous tree growing up to $40 \mathrm{~m}$ tall. Mature bark is grayish and young branches are copiously marked with lenticels (Figure 2.A). The branches and leaves are whorled, each whorl having 4-10 leaves (Figure 2.B). The leaves are leathery, upper side is glossy, while the underside is greyish. Leaves are narrowly obovate to very narrowly spathulate, base cuneate, apex usually rounded; lateral veins occur in 25 to 50 pairs, at $80-90^{\circ}$ angles to the midvein. The tree can be easily recognized by its many, sessile-flowered, branched umbellate cymous type of inflorescence and pendulous bunches of 30-60 cm long, bean-like follicles (Bhat 2003) (Figure 2.C). This tree is commonly called 'Haale mara' or 'Maddale mara' in Kannada and 'Paale' or 'Baliyendra mara' in Tulu. Its ayurvedic name is 'saptaparna' and the English common names are 'devil's tree, dita bark tree, etc.

\section{RESULTS AND DISCUSSION}

\section{Alstonia scholaris in ethnomedicinal tradition}

The tribal and non-tribal communities of Coastal Karnataka use A. scholaris for the treatment of various ailments such as fever, asthma, leucorrhea, eczema, indigestion and also to heal spider bites. Information on part used, method of preparation and the names of the communities from which such uses are recorded is provided in table 1 .

An annual health-related ritual involving $A$. scholaris is popularly followed by both the tribal and non-tribal communities of the study area. Members of the families belonging to these communities, especially those residing in the rural areas, drink a bitter juice prepared by grinding the stem bark of this tree along with seeds of 'jeerige' or cumin (Cuminum cyminum Linn., Umbelliferae) and 'adde munchi' or black pepper (Piper nigrum L., Piperaceae), on the new moon (amavasya) day of 'aati' month of the traditional ' $t u l u$ ' calendar that extends from mid-July to mid-August. Instead of the juice, a decoction of the stem bark is also used. Usually, the elder of the family collects the stem bark by pealing it with the help of stone or blunt instrument like a hammer, early in the morning before sunrise (Figure 3.A). Use of any sharp metal implements like a knife or sickle is discouraged for bark collection, and doing so is believed to reduce the medicinal power of the bark. Prayers are offered to the tree before gathering the bark.

This juice or decoction which is known as 'kahi maddu' or 'kaipe mard' in the local languages, meaning 'bitter medicine', is consumed early in the morning on empty stomach. The traditional belief behind this bitter medicine drinking practice is that it keeps away all diseases and ensures good health, throughout the year. The drinking of the bitter medicine is usually followed by eating a 'rice dish' prepared by cooking brown rice along with coconut milk and seeds of 'menthe' (Trigonella foenum-graecum L., Fabaceae).

This study indicates that $A$. scholaris is an important plant in the ethnomedicinal tradition of Coastal Karnataka, India. Of the several ethnomedicinal claims from the study area, its use against all types of fevers is particularly noteworthy as this particular information is recorded from all the tribal and other communities involved in the present study. Similar use has also been found in another tribe called the Gowlis of Uttara Kannada District (Bhandary et 
al. 1996) and in the folk-medicine of Sagar taluk of Karnataka (Rajkumar and Shivanna 2010). It is used as a bitter tonic against several disorders such as fevers including malaria and cholera, asthma, bronchitis, chest pain, diarrhea, eye complaints, rheumatism, snake-bite, stomach-ache, ulcers and headache in the ethnomedicine of other parts of India (Jain 1991, Pratyush et al. 2011, Khyadea et al. 2014). Detailed pharmacognostic evaluation of Alstonia scholaris roots has been reported by Sreya et al. (2019).

The data on medicinal properties and uses of $A$. scholaris mentioned in literature on Indian medicinal plants used in Ayurveda and other classical systems is summarized in table 2. It is used in various Ayurvedic preparations like Saptaparnasatvadi vati, Saptachadadi vati, Saptachhadadi vati, Saptacchadadi taila, Saptacchadadi kvatha and Saptaparna ghanasara (Meena et al. 2011). This plant has also been subjected to extensive pharmacochemical investigations (Pratyush et al 2011, Baliga 2012 , Khyadea et al. 2014, Arora and Rai 2015, Haritha et al. 2019). Some of the important results of such pharmacological studies are summarized in table 3. Nearly 169 alkaloids have been reported, along with iridoids, coumarins, flavonoids, and steroids from this plant (Pandey et al. 2020). Several pharmacologically active compounds such as alstonine, echitamine chloride, villalstonine, lupeol acetate, scholaricine, etc. have been isolated from this plant (Arulmozhi et al. 2007). Strictamine isolated from this plant has shown antiviral activity equivalent to that of acyclovir (Pandey et al. 2020).

All these data on traditional uses and pharmacological activities support the ethnomedicinal uses of $A$. scholaris against fever, asthma, eczema and digestive disorders by the indigenous communities of coastal Karnataka. However, the effectiveness of this plant against fever, especially against malarial fever, is controversial as some pharmacological studies have shown positive results while others did not show any anti-malarial activity (Gandhi and
Vinayak 1990; Keawpradub et al. 1991). However, a recent study conducted on control and prevention of malaria by Naulu Tribe in Seram Island of Central Maluku Regency is worth mentioning in this regard. The Naulu is one of the remote tribes in Seram Island which is known to be a malaria-endemic area, but the incidence of malaria reported in the people of this tribe is very low. Further, microscopic examination of 100 blood samples collected from this tribe for Plasmodium showed that only two samples were positive for malaria. Efforts to know the reason for this through in-depth interviews with the tribe revealed that traditional methods followed by them over generations for prevention and self-treatment of malaria are highly effective. These practices involved consuming herbal fumes, bitter foods and drinking water boiled with stem bark Alstonia scholaris, locally called 'pule', and other herbs (Marasabessy et al. 2019).

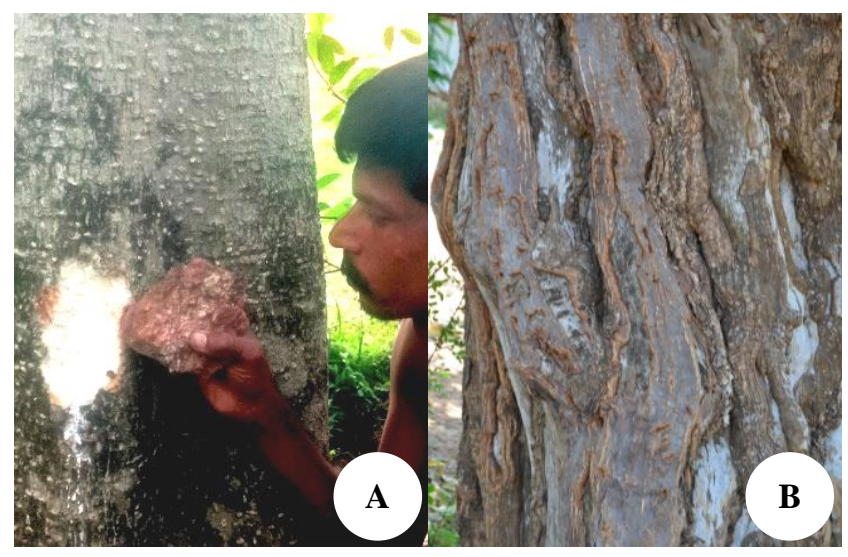

Figure 3.A. Demonstration of traditional method of Alstonia scholaris bark harvest using a stone piece, for preparing the traditional bitter medicine. B. Trunk of a tree showing scars of bark removal during previous years

Table 1. Ethnomedicinal uses of Alstonia scholaris in coastal Karnataka

\begin{tabular}{llll}
\hline Ailments & Part used & Method of use & Ethnic group \\
\hline Fever & Stem bark & Juice with sugar/Decoction, orally taken. & Non-tribals and Tribals \\
Leucorrhoea & Stem/root bark & $\begin{array}{l}\text { Juice is taken orally on empty stomach, early in the } \\
\text { morning }\end{array}$ & Non-tribals \\
Asthma & Leaf & Juice with honey, orally taken & Non-tribals \\
Eczema & Stem bark & Poultice with coconut oil applied externally. & Koragas \\
Indigestion/constipation & Stem bark & Decoction is taken orally. & Non-tribals \\
Spider bite & Stem bark & Paste with lime juice applied externally. & Non-tribals \\
\hline
\end{tabular}

Table 2. Medicinal properties and uses of Alstonia scholaris in Ayurveda and other classical medicinal systems of India

\begin{tabular}{lll}
\hline Properties & Useful in the treatment of & Reference \\
\hline $\begin{array}{l}\text { Febrifuge, antipyretic, spasmolytic, antidysenteric, } \\
\text { uterine stimulant, hypotensive, digestive, laxative, } \\
\text { depurative, galactagogue, cardiotonic and tonic. }\end{array}$ & $\begin{array}{l}\text { Fevers including malarial, abdominal disorders, } \\
\text { diarrhea, dysentery, dyspepsia, leprosy, skin diseases, }\end{array}$ & Warrier et al. 1994, \\
asthma, bronchitis, cardiopathy, helminthiasis, debility & & \\
\hline
\end{tabular}


Table 3. Reported pharmacological activities of Alstonia scholaris

\begin{tabular}{|c|c|}
\hline Activities & Remarks \\
\hline $\begin{array}{l}\text { Antimalarial/ } \\
\text { Antiplasmodial }\end{array}$ & $\begin{array}{l}\text { Petroleum ether and methanol extracts of the bark did not show anti-malarial activity in } \\
\text { mice infected with Plasmodium berghei. However, dose-dependent improvement and } \\
\text { delayed mortality of infected animals was observed. } \\
\text { Methanolic extracts of stem bark showed activity against K1 strain of Plasmodium } \\
\text { falcifarum cultured in human erythrocytes. }\end{array}$ \\
\hline Antimicrobial & $\begin{array}{l}\text { Chloroform and carbon tetrachloride extracts of bark showed strong zone of inhibition } \\
\text { and spectrum of activity against some bacteria and fungi. } \\
\text { Methanolic extracts of leaf, stem and root bark showed broad-spectrum activity. }\end{array}$ \\
\hline
\end{tabular}

Antidiarrhoeal/ Antispasmodial

Antioxidant activity

Analgesic and anti-inflammatory

Antiulcer

Anthelmintic

Antivenom

activity

Hepato-protection

Anti-asthmatic/ expectorant

Molluscicidal/anticholinesterase Antidiabetic

Anticancer

Immuno-

modulation

Radiation protection

Hypertension

Wound healing

Nephro-protection
Aqueous and alcoholic extracts of the bark showed antidiarrhoeal activity in mice. Crude extract of bark provided protection against castor-oil induced diarrhea in mice and spasmolytic activity in isolated rabbit jejunum preparation.

In DPPH free radical scavenging assay, IC50 value of methanolic extract was found to be $39 \mathrm{~g} / \mathrm{ml}$ which indicates mild to moderate antioxidant activity

Ethanolic extract of leaves showed significant decrease of experimentally induced pain and inflammation.

Ethanolic extract and alkaloid fractions of leaves reduced acetic acid-induced writhings and xylene induced ear edema in mice. Alkaloids also exhibited inhibition of inflammatory mediators in in vitro tests.

Ethanolic extract-treated rats did not develop ulcer.

Alcoholic extract of stem bark showed significant activity against Ascardia galli.

Aqueous extract of leaves neutralized viper venom-induced minimum lethal action (MLD), minimum edema activity (MED), minimum defibrinogenating action (MDD), minimum necrotizing action (MND) in 18-20 gms mice.

Extracts provided protection against experimentally induced liver injuries in mice.

Ethanol extract showed bronchodilatory activity in rats.

The alkaloid fraction of leaves showed significant anti-asthmatic, anti-tussive and expectorant activity in mice and guinea pig models. The alkaloid picrinine was found to be responsible for anti-tussive and anti-asthmatic activity, in in vivo tests.

Aqueous extract of stem bark showed strong activities against Lymnaea accuminata.

Aqueous methanolic extract of dried leaves showed potent alpha-glucosidase inhibitory activity.

Methanol extracts of root bark showed cytotoxic activity against lung cancer cell lines. The alkaloid villalstonine was highly active.

Extracts were active against fore-stomach carcinogenesis in mice.

Various extracts and alkaloid fractions showed significant in vitro anticancerous effect on cultured human neoplastic cell lines and in vivo effect on carcinoma bearing mice.

Bark extract showed chemopreventive action in DMBA-induced skin carcinogenesis in mice

Aqueous extract of the stem bark increased lytic activity of peritoneal exudate cells of mice against $E$. coli. It also induced cellular immune response and inhibited delayed type of hypersensitivity reaction. However, it had no effect on primary antibody level.

Extracts of stem bark provided protection against radiation-induced hematological and biochemical damages in mice.

Clinical study on 30 patients with bark decoction reduced elevated diastolic blood pressure

Ethanol and aqueous extracts promoted wound healing in excision, incision and dead space wound models.

Ethanolic leaf extracts showed high potential to minimize cisplatin (cDDP) induced renal damage as indicated by restoration of biochemical, antioxidant and histopathological alterations in nephrotoxic rats as compared to aqueous extracts.
References

Gandhi and Vinayak (1990)

Keawpradub et al. (1999)

Bellah et al. (2017)

Khan et al (2003), Khyadea and Vaikos (2009), Mohammad and Sarwar (2019)

Patil et al. (1999)

Shah et al. (2010)

Bellah et al. (2017)

Arulmozhi et al. (2007)

Shang et al. (2010a)

Arulmozhi et al. (2007)

Arulmozhi et al. (2007)

Sumana and Rituparna (2017)

Lin et al. (1996)

Channa et al. (2005),

Shang et al. (2010b)

Singh and Singh (2003)

Jong-Anurakkun et al. (2007)

Keawpradub et al. (1997

Jagetia et al. (2003)

Jahan (2009)

Iwo et al. (2000)

Gupta (2008)

Bhogayata et al. (2009)

Arulmozhi et al.

(2007)

Verma et al. (2019) 
The traditional practice of mass drinking of the bitter juice or decoction of $A$. scholaris to prevent illnesses appears to be interesting and scientifically meaningful when interpreted on the background of the timing of this practice and the wide range of confirmed curative properties of this plant. The 'aati' month of Tulu calendar falls during the months of July and August which coincides with heavy monsoon rainfall in coastal Karnataka. These months are characterized by sudden changes in weather conditions and this is also the period of hectic agricultural activities in the area due to which people have to be working hard in the open fields. Therefore, they are obviously more exposed and vulnerable to health problems, especially infectious diseases. This perhaps justifies the need for mass administration of a preventive medication during this month. On the other hand, A. scholaris has been confirmed to have antimicrobial, anti-diarrheal, antidysenteric, anti-inflammatory, anti-asthmatic, anticancerous and immune-modulation activities, besides the controversial antipyretic and anti-malarial (Table 3).

It is also interesting to note that a study on toxicity effects of various doses of hydroalcoholic extract of $A$. scholaris has shown that the acute toxicity in mice depended on the season of collection of plant samples. The least toxicity was observed in the extract prepared from the bark collected in the monsoon season while the highest acute toxicity was observed in the summer collection, followed by winter (Baliga et al. 2004). Another comparative study of the concentrations of active principles in the bark juice of this tree has indicated the presence of maximum concentration of active principles in the sample collected on the particular new moon day of 'aati' month (Adiga et al. 2019). This is in comparison to the samples collected three days before the particular new moon day and three days after. All the above facts provide a scientific basis for the use of $A$. scholaris in the traditional folk-medicinal ritual and also the annual timing of the event.

Another noteworthy aspect of $A$. scholaris medicinal ritual is the cultural restriction that bark is to be harvested only by using stone pieces or blunt objects, and any type of sharp metal instruments should not be used. In addition, bark harvest has to be made only by an elder of the family, in the early morning before dawn. These taboos may be indirectly contributing to regulate or minimize the quantity of bark harvested or they ensure sustainable harvest of the useful part of the tree (Figure 3.B). Similar restrictions on plant harvest, such as removal of tree bark only from the sunny side of the tree, no harvesting after dark, etc. have also been reported from other indigenous communities like the Maroons of Suriname (Tinde and Havinga 2008).

\section{Alstonia scholaris in religious tradition}

An interesting religious tradition commonly observed among the Tulu language-speaking indigenous communities belonging to Hindu religion, of the Dakshina Kannada district of the study area, is the worship of $A$. scholaris tree during a festival called 'Deepavali' which means the 'festival of lights'. During the three days of this festival, a straight branch of A. scholaris measuring about 2-3 feet in length and 2-3 inches in girth, is cut from a nearby tree and is made to stand erect on ground in the front yard, near the main entrance of the home. Usually, this structure is installed adjacent to the customary sacred basil plant (Ocimum tenuiflorum L., Lamiaceae) maintained in front of the houses (Figure 4.A). The branch is cut in such a way that part of its retained whorl of subbranches forms a crown-like structure at the tip. This crown is used to hold a lamp made of coconut shells (Cocos nucifera L., Arecaceae), locally called 'thibile', in which a cotton wick wetted in coconut oil is lighted every night during the festival. The branch is also decorated with fresh wildflowers of 'dasavala' (Hibiscus rosa-sinensis L, Malvaceae), 'gonde poo' (Allamanda cathartica L., Apocynaceae), and 'paade poo' (Polycarpaea corymbosa (L.) Lam., Caryophyllaceae) (Figure 4). According to the local religious belief, the structure formed by decorated Alstonia branch is called 'Baliyendra mara' (tree dedicated to Baliyendra) which symbolizes a demon king in Hindu mythology called 'Bali'. All members of the family join during the worship by lighting the lamp and loudly shout the name of 'Bali'. Dishes made from rice and milk are also kept in a banana plant leaf, as offerings to Bali (Figure 4.B). This religious ceremony of A. scholaris worship is linked to the local version of the story of King Bali, which is narrated below.

A king of demons by name 'Bali' was very powerful and he was a menace to all the gods. To kill him and rescue gods from his clutches, the Hindu god of creation 'Vishnu' appeared in front of Bali as a dwarf called' Vamana'. Vamana requested Bali for granting him a piece of land of the size of his three tiny footsteps. Bali promised Vamana three footsteps of ground as requested. Immediately, Vamana transformed himself into a giant and covered the entire earth with the first step, and the entire heavens with the second step. Though a demon, Bali was an honorable person who never went back on his word once granted. Seeing that there was no place for the third step, Bali, accepting defeat and to save his honor, knelt in front of god and asked him to place the third step on his own head. Vamana kept his third step on Bali's head and killed him by pushing him down the earth.

Before doing so, pleased by king Bali's determination to keep his promise, Vamana appeared before Bali in his real form of god Vishnu. He offered Bali to seek his last wish, if any, which will be certainly fulfilled. Bali wished that his memory should be immortal on earth and he must be given a chance to return to the earth once every year, during which he must be worshipped by all people. This wish was granted by Lord Vishnu and he promised Bali that he would be reborn on earth as a tree which will be known by his name. And, he may also return to earth every year during Deepavali festival for being worshipped.

People of Tulunadu believe that $A$. scholaris tree is the re-incarnation of Bali on earth. Therefore, they call it after his name as 'Baliyendra mara' and worship its branch during Deepavali festival, during which Bali is believed to be visiting the earth. 

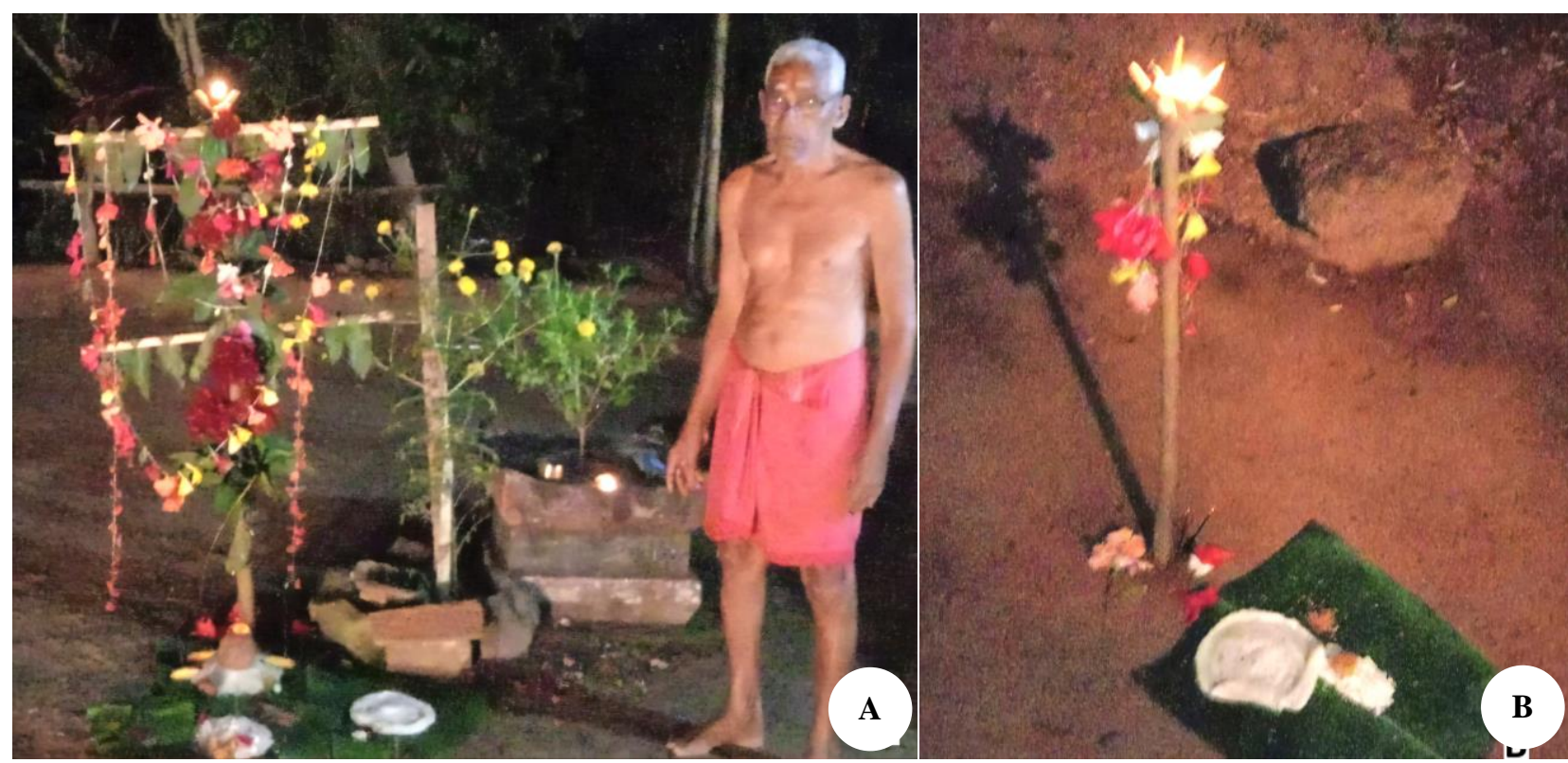

Figure 4.A. Worship structures made from the branch of Alstonia scholaris decorated with wild flowers. The sacred tulasi plant (Ocimum tenuiflorum). B. Lighted traditional lamps placed atop the structures and food offerings placed in banana leaf on the ground

The tradition of tree worship is common in India since ancient times and species like Saraca asoka (Ashoka), Ficus spp. (Banyan), Aegle marmelos (Bhel), Mimusops elengi (Bakula), Azadirachta indica (Neem), Messua ferrea (Naga Keshara), etc., are the most popular sacred trees which are believed to be the abodes of gods (Rao 2002). However, worshipping A. scholaris, which is popularly called the 'Indian Devil's tree' in English because of the belief that they harbor evil spirits and witched powers, is not a very popular practice. In fact, among some tribals like Hill-Tiwas of Assam, wood of A. scholaris should not be taken inside the houses as it is a taboo (Teron and Borthakur 2014). This tree has been venerated and considered as sacred by a few tribal communities, such as the Mikirs of Assam (Rao 2002), Tripuris of Tripura (Sharma et al. 2014) and Thacchanda Moopans of Kerala (Sreejisha and Jesurathnam 2012). These tribes generally believe that the souls of their ancestors live on A. scholaris trees. It is also a common species in the sacred groves called 'Kavus' of Kerala and finds a place in the rituals associated with worship of serpent god and 'theyyam' spirits (Chandrashekara et al. 2002). Besides, it's also interesting to note that the traditional masks used during temple festivals and other celebratory performances in Bali island of Indonesia are usually carved from the wood of $A$. scholaris (pule wood), cut from trees with due religious ceremony (Eiseman 1996).

Presently, this practice of $A$. scholaris worship is gradually decreasing in the study area and can be observed only in rural houses where families are still accompanied or headed by people of elder generations who are still attached to the traditions. The younger generation has gradually lost faith in the traditional practices and also getting delinked from their traditional roots owing to modern education and employment. Another contributing factor is the difficulty in collecting branches of A. scholaris trees which have become rare in the study area. Instead, easily available alternative such as the pseudo-stem of banana plant is used as an alternative for the worship. However, popularising and retaining this kind of ethnobiological tradition, which is an important dimension of nature worship, is essential to strengthen the bond between modern human culture and nature.

\section{REFERENCES}

Adiga HS, Aswath Ram HN, Adiga RS, Jagadish PC. 2019. Evaluating the significance of the traditional use of Alstonia scholaris Linn. in Tulunadu region of South India. Res J Pharm Technol 12 (8): 38783882 .

Arora A, Rai Y. 2015. A Review: Phytochemistry, Ethnobotanical and Pharmacological activities of Alstonia scholaris $\mathrm{R} . \mathrm{Br}$ (Apocynaceae). Intl J Adv Res 3 (8): 584-590.

Arulmozhi S, Mazumder PM, Purnima, A, Sathiya LN. 2007. Pharmacological activities of Alstonia scholaris Linn. (Apocynaceae)-A Review. Pharmacogn Rev 1 (1): 163-170.

Baliga MS, Jagetia GS, Ulloor JN, Baliga MP, Venkatesh P. 2004. The evaluation of the acute toxicity and long term safety of hydroalcoholic extract of Sapthaparna (Alstonia scholaris) in mice and rats, Toxicol Lett 151 (2): 317-326.

Baliga MS. 2012. Review of the phytochemical, pharmacological and toxicological properties of Alstonia Scholaris Linn. R. $\mathrm{Br}$ (Saptaparna). Chin J Integr Med. DOI: 10.1007/s11655-011-0947-0.

Bellah SM, Tahasina JA, Rezaul K, Billah SMS, Alireza SM, Md Obaidullah. 2017. Evaluation of Antioxidant, Antimicrobial and Cytotoxic Activity of the Bark of Alstonia scholaris. Clin Pharmacol Biopharm. 6: 2. DOI: 10.4172/2167-065X.1000168.

Bhandary M J, Chandrashekar KR. 2009. Herbal therapy for herpes in the ethnomedicine of Coastal Karnataka. Indian J Traditional Knowledge. 10 (3): 528-532.

Bhandary MJ, Chandrashekar K R, Kaveriappa KM. 1995. Medical Ethnobotany of the Siddis of Uttara Kannada district, Karnataka. India. J Ethnopharmacol. 47: 149-156. 
Bhandary MJ, Chandrashekar KR, Kaveriappa KM. 1996. Ethnobotany of the Gowlis of Uttara Kannada, Karnataka, J Econ Taxon Bot 12: 244 249.

Bhandary MJ, Chandrashekar KR. 2001. Treatment for poisonous snakebites in the ethnomedicine of Coastal Karnataka. J Med Arom Plant Sci 22: 505-510

Bhandary MJ, Chandrashekar KR. 2003. Veterinary herbal medicine of Coastal Karnataka. J Econ Taxon Bot 27: 645-655

Bhat, KG. 2003. Flora of Udupi. Indian Naturalists, Udupi, Karnataka

Bhogayata, K, Sharma PP, Patel BR. 2009. A clinical evaluation of Saptaparna (Alstonia scholaris) on essential hypertension. Ayu 30 (3): 318-322.

Binu S, Nayar TS, Pushpangadan P. 1992. An outline of ethnobotanical research in India. J Econ Taxon Bot 10: 405-428.

Chandrashekara UM, Joseph SP, Sreejith KA. 2002. Ecological and socio- cultural dimensions of sacred groves of northern Kerala. Man in India 8 (2): 323-340.

Channa S, Dar A, Ahmed S, Rahman A. 2005. Evaluation of Alstonia scholaris leaves for broncho-vasodilatory activity. J Ethnopharmacol 97 (3): 469-476.

Choudhary J. 2012. Tree Worship Tradition in India and Origin of Jagannath Cult. Odisha Review Jun 2012: 55-57.

Eiseman FB. 1996. Mask making: supernatural and craftsmanship. In: Eiseman FB (ed.). Bali Sekala and Niskala, Vol. 2: Essays on Society, Tradition and Craft. Periplus Books, Singapore.

Gamble JS. 1967. Flora of Presidency of Madras, Vol I-III. Botanical Survey of India, Calcutta.

Gandhi M, Vinayak VK, 1990. Preliminary evaluation of extracts of Alstonia scholaris bark for in vivo antimalarial activity in mice. J Ethnopharmacol. 29 (1): 51-57.

Gupta U. 2008. Amelioration of radiation-induced hematological and biochemical alterations by Alstonia scholaris Extract, Integrative Cancer Ther 7 (3): 155-161.

Haritha BMM, Ananya B, Karunakar H, Shabaraya AR. 2019. Alstonia Scholaris: A Brief Review. Intl J Pharm Sci Rev Res 59 (2): 31-33.

Harsha VH, Hebbar SS, Shripathi V, Hegde GR. 2003. Ethnomedicobotany of Uttara Kannada District in Karnataka, India, Plants in the treatment of skin diseases. J Ethnopharmacol 84: 37-40.

Harsha VH, Shripathi V, Hegde GR. 2006. Ethnoveterinary practices in Uttara Kannada District of Karnataka. Indian J Trad Knowled 4: 253 258

Iwo MI, Soemardji AA, Retnoningrum DS, Sukrasno DM. 2000 Immuno-stimulating effect of pule (Alstonia scholaris L., R. Br., Apocynaceae) bark extracts. Clin Hemorheol Microcirc 23 (2-4): 177 183.

Jagetia GC, Baliga MS, Venkatesh P. 2003. Effect of saptaparna (Alstonia scholaris Linn.) in modulating the benzo (a)pyrene-induced forestomach carcinogenesis in mice. Toxicol Lett 144 (2): 183-193.

Jagetia GC, Baliga MS. 2005. Evaluation of anticancer activity of the alkaloid fraction of Alstonia scholaris (Sapthaparna) in vitro and in vivo. Phytother Res 20 (2): 103-109.

Jahan S. 2009. Anticancer Activity of an Indian medicinal plant, Alstonia scholaris, on skin carcinogenesis in mice. Integrat Cancer Ther 8 (3): 273-279.

Jain, SK. 1991. Dictionary of Indian Folk-medicine and Ethnobotany Deep Publications, New Delhi.

Jong-Anurakkun N, Bhandari MR, Kawabata J. 2007. $\alpha$ Glucosidase inhibitors from Devil tree (Alstonia scholaris). Food Chem 103 (4): 1319-1323.

Keawpradub N, Houghton PJ, Amooquaye EE, Burke PJ. 1997. Activity of extracts and alkaloids of Thai Alstonia species against human lung cancer cell lines. Planta Med 63 (2): 97-103.

Keawpradub N, Kirby GC, Stele JCP, Houghton PJ. 1999. Antiplasmodia activity of extracts and alkaloids of three Alstonia species from Thailand. Planta Med 65 (8): 690-694.

Khan MR, Omoloso AD, Kihara M. 2003. Antibacterial activity of Alstonia scholaris and Leea tetramera, Fitotherapia 74 (7-8): 736740 .

Kher CP. 2007. Indian Medicinal plants-An Illustrated Dictionary. Springer Verlag, Berlin.

Khyade MS, Vaikos NP. 2009. Phytochemical and antibacterial properties of leaves of Alstonia scholaris R. Br. Afr J Biotechnol 8 (22): 64346436.

Khyadea MS, Deepak MK, Nityanand PV. 2014. Alstonia scholaris (L.) R. Br. and Alstonia macrophylla Wall. ex G. Don: A comparative review on traditional uses, phytochemistry and pharmacology. J Ethnopharmacol 153: 1-18.

Lalramnghinglova H, Jha LK. 1999. Ethnobotany: A Review. J Econ Taxon Bot 23: 1-27

Lin SC, Lin CC, Lin YH, Supriyatna S, Pan SL. 1996. The protective effect of Alstonia scholaris $\mathrm{R}$. Br. on hepatoxine induced acute liver damage. Am J Clin Med 24 (2): 153-161.

Manilal KS. 1989. Linkages of ethnobotany with other Sciences and Disciplines. Ethnobotany 1: 15-24.

Marasabessy NB, Soedirham O, Dachlan YP. 2019. Prevention and Control of Malaria-Measures Used by People of Naulu Tribe in Seram Island, Central Maluku Regency. Indian J Public Health Res Dev 10 (8): 1447-1451.

Medeiros PM, Almeida ALS, Lucena RFP, Souto FJB, Albuquerque UP. 2014. Use of Visual Stimuli in Ethnobiological Research-Methods and techniques. In: Albuquerque U, da Cruz Cunha L, Lucena R, Alves R (eds.). Ethnobiology and Ethnoecology. Springer, New York.

Meena AK, Garg N, Nain J, Meena RP, Rao MM. 2011. Review on ethnobotany, phytochemical and pharmacological profile on Alstonia scholaris. Intl Res J Pharm 2 (1): 49-54.

Mohammed H, Sarwar J. 2019. Microbial activity of Alstonia scholaris leaf extracts against pathogenic microbes. J Res Biol Med Sci 1 (1): $1-5$.

Pandey K, Shevkar C, Bairwa K. 2020. Pharmaceutical perspective on bioactive from Alstonia scholaris: ethnomedicinal knowledge, phytochemistry, clinical status, patent space, and future directions. Phytochem Rev. DOI: 10.1007/s11101-020-09662.

Patil RS, Juvekar AR, Joglekar SN, Shamkuwar PB, Nimbkar SR. 1999. Study of antidiarrhoeal activity of Alstonia scholaris bark. Indian Drugs 36 (7): 463-465.

Pratyush K, Chandra SM, Joel J, Lipin DMS, Arun KTV, Thankamani V. 2011. Ethnobotanical and pharmacological study of Alstonia (Apocynaceae)-A Review: J Pharm Sci Res 3 (8): 394-1403.

Pullaiah T, KV Krishnamurthy, Bir Bahadur (Eds). 2017. Ethnobotany of India (Vols 1-5). Apple Academic Press, Oakville, Canada

Pushpangadan P, George V. 2010. Ethnomedical practices of rural and tribal populations of India with special reference to the mother and child care. Indian J Trad Knowl 10: 9-17.

Rajkumar N, Shivanna MB. 2010. Traditional herbal medicinal knowledge in Sagar taluk of Shimogga district, Karnataka, India, Indian J Nat Products Res 1 (1): 102-108.

Rao RR. 2002. Tribal wisdom and conservation of biological diversity: The Indian Scenario. In: Stepp JR, Wyndham FS, Zarger RK (eds.). Proceedings of the Seventh International Congress of Ethnobiology. University of Georgia Press, Athens, GA.

Saldhanha CJ. 1984. Flora of Karnataka, Vol 1. Oxford \& IBH Publishers, New Delhi.

Schippmann U, Leaman DJ, Cunningham AB. 2002. Impact of cultivation and Gathering of Medicinal Plants on Biodiversity: Global Trends and Issues. Inter-Department Working Group on Biology Diversity for Food and Agriculture, FAO, Rome.

Shah AJ, Saqib AG, Akber JZ, Muhammad NG, Anwarul HG. 2010. Antidiarrhoeal and spasmolytic activities of the methanolic crude extract of Alstonia scholaris L. are mediated through calcium channel blockade. Phytother Res 24 (1): 28-32.

Shang J, Xiang-Hai C, Tao F, Yun-Li Z, Jing-Kun W, Lu-Yong Z, Ming Y, Xiao-Dong L. 2010a. Pharmacological evaluation of Alstonia scholaris: Anti-inflammatory and analgesic effects. J Ethnopharmacol 129 (2): 174-181

Shang J, Xiang-Hai C, Yun-Li Z, Tao F, Xiao-Dong L. 2010 b. Pharmacological evaluation of Alstonia scholaris: Anti-tussive, antiasthmatic and expectorant activities. J Ethnopharmacol 129 (3): 293298.

Sharma M, Sharma CL, Debbarma J. 2014. Ethnobotanical studies of some plants used by Tripuri tribe of Tripura, NE India with special reference to magico-religious beliefs. Intl J Plant Animal Environ Sci 4 (3): 519-528.

Singh SK, Singh A. 2003. Molluscicidal and anti-cholinesterase activity of Alstonia scholaris plant against freshwater snail Lymnaea acuminata. Pakistan J Biol Sci 6 (16): 1442-1446.

Smith-Hall, C, Larsen HO, Poulio M. 2012. People, plants and health: a conceptual framework for assessing changes in medicinal plant consumption. J Ethnobiol Ethnomed 8: 43. DOI: :10.1186/17464269-8-43. 
Sreejisha VP, Jesurathnam D. 2012. Socio-psychological Reflection of Religious Mobility: A Case of Thachanadan Moopan. Anthropologist 14 (2) 155-166.

Sreya D, Manosi D, Avijit B, Mruthyumjaya MR. 2019. Pharmacognostical evaluation of Alstonia scholaris (L.) R.Br (Saptaparna) roots. J Pharmacogn Phytochem 8 (2): 2096-2101.

Sumana SA, Rituparna G. 2017. Preliminary screening of aqueous Alstonia scholaris Linn Bark extracts for antivenom activity in experimental animal model. IOSR J Dent Med Sci 16 (5): 120-123.

Teron R, Borthakur S. 2014. Ethnobotanical appraisal of the Hill-Tiwas of Assam, India. Pleione 8 (1): 109-119.

Thomas E, Vandebroek I, Van Damme P. 2007. What works in the field? A comparison of different interviewing methods in ethnobotany with special reference to the use of photographs. Econ Bot 61: 376-384.
Tinde VA, Havinga R. 2008. Sustainability aspects of commercial medicinal plant harvesting in Suriname. For Ecol Manag 256: 15401545 .

Vedprakash 1998. Indian medicinal plants-Current status-1. Ethnobotany. 10: $112-121$

Verma PK., Raina R., Sultana M. 2019. Nephroprotective Potential of Alstonia scholaris in Cisplatin Induced Nephrotoxicity in Experimental Animals. Proc Natl Acad Sci India Sect B Biol Sci 89: 43-52. DOI: 10.1007/s40011-017-0881-9.

Warrier PK, Nambiar VPK, Kutty CR. 1994. Medicinal Plants of India, Vol 1. Orient Longman Ltd., Madras. 